\section{ON THE ENDOSCOPIC APPEARANCES OF THE URETHRA.}

Br CHRISTOPHER HEATH, EsQ., F.R.C.S., ASSISTIYT-SERGEOY TO AND LECTCRER OY ANATOMI AT THE WESTMINSTER HOSPITAI.

My paper "On the Endoscope as a Means for the Diagnosis and Treatment of Urethral Disease" having served Mr. Henry "Thompson as a peg on which to hang two communications to the columns of ThE LANCET, I would renture a few remarks in reply.

Mr. Thompson's first communication can be dismissed in a few words, since its objects were simply to explain his long acquaintance with the endoscope; his belief that its employment would be attended with little advantage; and his preference for what he calls the tactum eruditum.

In his second article, however, he takes me to task for a statement respecting the contraction of the muscular fibres of the urethra, which requires a more extended notice. My statement was, "I have noticed in perfectly healthy urethras that there is a constant vermicular contraction of the wall of the canal, apparently passing towards the bladder; and this accounts for the well-known fact that foreign bodies in the urethra tend to pass in that direction." Mr. Thompson maintains that the movement, which he has also seen, "is precisely in the opposite direction; and also that foreign bodies have a strong tendency to pass outwards to the meatus, and not inwards to the bladder." In writing my paper, I recorded what I saw, or at least believed I saw; and it must be remembered that the contraction I witnessed was in the presence of a foreign body, namely, the tube of the endoscope. This contraction was towards the bladder, and would, as I believe, have tended to draw a foreign body, of smaller size and completely within the grasp of the canal, in the same direction. The experience of most surgeons corresponds, I believe, with my own as to the tendency of foreign bodies entirely within the urethra to travel on to the bladder; and even Mr. Thompson's own recorded experience goes the same way. In THE LANCEI - of Nov. 28th, 1863, he recorded a remarkable case of hair-pin in the male urethra (a case upon which I made some remarks in The LuAnceT of Jan. 30th, 1864): here Mr. Dunn, who saw the patient immediately after the accident, found the pin already an inch and a half from the meatus; and Mr. Thompson, two hours after, found the pin "at least four and a half inches from it." Mr. Thompson has also recorded a case* where he removed a mass of sealing-wax from the bladder, which had been introduced into the urethra when in the form of the ordinary stick. Sir William Fergusson has recordedt a case where an entire elastic bougie, which had slipped within the urethra, found its way into the bladder, and was extracted by that gentleman with the lithotrite. Mr. Coulson removed by lateral lithotomy a piece of thermometer-tube; ${ }_{-+}^{+}$and in a case under my own care I removed a piece of gutta-percha bougie with the lithotrite. $\$$ Examples might be multiplied showing that the experience of a great number of surgeons contradicts Mr. Thompson's statement, but I will only refer to one more-namely, a casell in which Mr. Henry Smith re. moved, by lithotomy, a glass flower-tube from the bladder of a man who had introduced it within the urethra with a string attached to it, and where, notwithstanding this precaution and the fact that both encls uere smooth, it travelled backwards, instead of forwards, as it ought to have done according to Mr. Thompson's theory.

No doubt the effect of the involuntary muscular fibre of the urethra is, as generally stated, to keep the canal closed, except at the fossa navicularis, immediately within the meatus, where the walls do not come in contact: this, so far from tending to eject matters from the urethra, tends rather to retain the ordinary mucous secretions within the canal; and it is only when these are greatly increased, as in gonorrhcea, that they, from force of gravity, find their way out. The ejection of the last few drops of urine depends, not on the passive contraction of the urethral fibres, but upon the sudden contraction of the accelerator urince muscle; and Mr. Thompson himself states

* The Laxcet, April 20th, $1861 . \quad$ \& Ibid., Dec. 6th, 1862.
+ Ibid., August 22nd, 1563. this in his work on Stricture, which, however, perhaps does not represent his present views on the physiolcgy of the urethra, any more than the strong recommendation of metallic instruments of a special curve contained in it does his own treatment by elastic bougies. The same may be said of the expulsion of injections and of bougies. With regard to the expulsion of fragments of stone, I am inclined to lay much greater stress upon the force of the urine washing over them than upon any muscular action whatever; and in this $I$ am confirmed by $\mathrm{Mr}$. Thompson himself, for at page 196 of his "Lithotomy and Lithotrity" he says-"Supposing, however, a fragment to have become arrested in the urethra, and the patient to be able nevertheless to relieve his bladder in a diminished stream, the pressure of the urine usually brings it forward in a few hours to the orifice."

No mention occurs of the alleged tendency of the urethra to thrust out foreign bodies in any of Mr. Thompson's published works, so far as I can ascertain; but in a letter from that gentleman on "Soluble Bougies" published in THE LANCET of July 14th, 1866, he expressly states that it is unnecessary to introduce the bougie more than two inches and a half up the urethra, for, "as the bougie dissolves, the liquefied material is slowly driven backwards (since its exit is barred in front by the plaster), and soon penetrates as far as to the bladder."

In conclusion, 1 may notice that Hunter, in his essay on Gonorrhœe, whilst stating that the muscular action of the urethra is principally from before backwards, says, "This action I believe is often inverted, as in spasmodic stranguries." Also that, under the head of Caruncles or Excrescences of the Urethra, he mentions "bodies rising from the surface of the urethra like granulations," thus bearing out the appearances seen with the endoscope, though, as he states, he had met with them in but two instances.

Cavendish-place, Oct. 29th, 1866.

\section{g. afthror}

OF THE PRACTICE OF

\section{MEDICINE AND SURGERY IN THE}

HOSPITALS OF LONDON.

Nulla autem est alia pro certo noscendi via, nisi quamplurimas et morborum et dissectionum historias, tum aliorum, tum proprias collectas habere, et int se comparare.-Morgagri De Sed. et Caus. Morb., lib. iv. Procmium.

\section{MIDDLESEX HOSPITAL.}

PUERPERAI CONVULSIONS, STHENIC AND PLETHORIC, WITHOUT ALBUMINURIA; GOOD RECOVERY; CHILD LIVING.

(Under the care of Dr. HALL DAVIS.)

THE following case of puerperal convulsions unaccompanied by albuminous urine, and not preceded by cedema, affords an illustration of the sthenic and plethoric form of the disease, as also of the efficacy of free depletion in its treatment. Delivery by forceps had failed to arrest the malady. The treatment adopted was in conformity with Dr. Davis's teaching in such a condition, and was judiciously carried out by the obstetric assistant at the hospital, Mr. William Draper. As most usual, the patient was a primipara. Her case is as follows:-

Mary D-_, aged nineteen, a well-developed, robust, plethoric woman. Has always lived well, and never had a day's illness. Has one sister, aged fourteen, who some years ago was subject to occasional epileptic seizures.

On July 25th, 1866, Mr. Draper was called by one of the midwives to see this patient in her primiparous labour. Before his arrival she had had two fits of convulsions, in which she had bitten her tongue and foamed at the mouth, her features being much distorted. He found the patient recovering from the second attack. She was in a semi-conscious condition. Face flushed; skin hot, but moist; tongue large and red, and lacerated by teeth; head hot; pupils rather contracted; pulse 120 , full, and with ditficulty compressible. Occasional slight muscular spasm. The child's head being at the pelvic outlet, where the midwife said it had been for about two hours and 